\title{
A Systematical Analysis Framework on Lululemon---- High-end Professional Brand Image and Close to life Promotion
}

\author{
Yuzhuo Diao ${ }^{1, *}$ \\ ${ }^{1}$ School of Economics and Management, Beijing Jiaotong University, 100091, Beijing, China \\ *Corresponding author. Email: 18726086@bjtu.edu.cn
}

\begin{abstract}
As the sportswear market continues to be sluggish and the global retail industry is in a weak state, lululemon, which started with yoga clothes, has developed rapidly and has become a sports brand comparable to Adidas and Nike. In recent years, with the development of China's economy, the yoga market has continued to grow. Lululemon also targeted the Chinese market for its next development strategy. This article analyses the brand strategy of lululemon's successful marketing strategy from three aspects: brand positioning, brand image shaping, and brand community culture. And used porter's five forces and the SWOT model to further analyse lululemon's strategic moves.
\end{abstract}

Keywords: SWOT model; Porter five forces; Market strategy.

\section{INTRODUCTION}

When we discuss the sporting goods market, it is more like a lifestyle industry. With the Chinese government's emphasis on sports for all and the increasing participation of young people in sports, this market has shown great potential [1]. The current market value of yoga in China has reached $\$ 10$ billion.

Lululemon is known as the first professional sports brand in Canada. In North America, it is a high-end sportswear brand for people to perform yoga and fitness. This brand started with yoga clothes, focusing on the women's sports market, with sales of $\$ 1.8$ billion in 2014 [2, 3]. Lululemon's brand strategy and marketing strategy are the key factors for success.

The brand has $80 \%$ to $85 \%$ awareness in Canada, about $45 \%-50 \%$ in the US market, and only $12 \%$ in China. Many brands have entered China in recent years, all expressing that they will open 300 to 400 stores within two years. This is not the way lululemon operates. It hopes to establish a sustainable business model in China [4]. Lululemon emphasizes deepening the community and building a deeper understanding through brand ambassadors, fitness studios, and consumers. Instead of promoting itself through largescale marketing and channel advertising [5].
Lululemon has been deeply involved in the North American market since its establishment 20 years ago $[6,7]$. However, it only entered China about 5 years ago. The popular forms of exercise in China include yoga, indoor spinning, CrossFit, boxing, etc., which are similar to Los Angeles, New York, or London. From a global perspective, sports events may have regional differences, but people's pursuit of an enterprising and mindful lifestyle is consistent. China is changing very fast. Nowadays, consumers generally have global awareness, and transparent market information makes the activities of the Chinese market almost synchronized with the global market [8].

Today's fitness sports market has ushered in a great leap. There are 415 million millennials in China, and how this generation of young people interact in the data age is different from other age groups. At the same time, their consumption behaviour also indicates the future direction of the market. The behaviour of Chinese consumers is extremely advanced, such as how to use WeChat. How to use social media software to connect to all aspects of life. From a technical point of view, China is far ahead in the global market. At the same time, consumers began to pay attention to sports and healthy lifestyles, which gave the brand a good opportunity for development.

In this work, we conduct a detailed analysis of the firm's financial situation, the consumer, and the 
strategy. Besides, we present the five forces analysis and SWOT analysis to this company. We give some conclusion. New brands all emerge from the fringe zone because strong brands already occupy the central zone. Yoga clothing brand Lululemon has emerged from many sportswear brands in just a few years, and it seems that it has evolved into a lifestyle rather than just a clothing brand. The rise of the middle-class era means that people begin to pay for the design, brand, social attributes, emotional elements, and other matters beyond the basic functions after the commodity economy is enriched. The design and aesthetics of the products have been greatly improved, slightly higher. Prices are completely acceptable to the average middle class. Brands with a strong sense of design will emerge in various fields, determined by the consumption habits and aesthetic taste of the middle class. Lululemon's design is an important reason for the high-end brand image. It not only sells products but also promotes yoga, sports, and a healthy lifestyle and spirit. Its packaging bags are filled with various inspirational slogans and life attitude slogans. This avoids product homogeneity and establishes a brand. Many people buy Lululemon as their daily wear, which not only shows the consumption level of their own class, but the price is not very high compared with high-end clothing, so the price has a great advantage. Last but not least, teaming up with local yoga masters is the key to victory.

The remainder of the paper is organized as follows. In section 2, we describe the financial situation of this company. In section 3 , we present its consumer and give an analysis framework. In section 4, we introduce the strategy of this firm. In section 5, we give a five forces analysis. In section 6, we present the SWOT analysis to this company. Finally, we summarize the conclusion in section 7 .

\section{FIRM FINANCIAL DESCRIPTION}

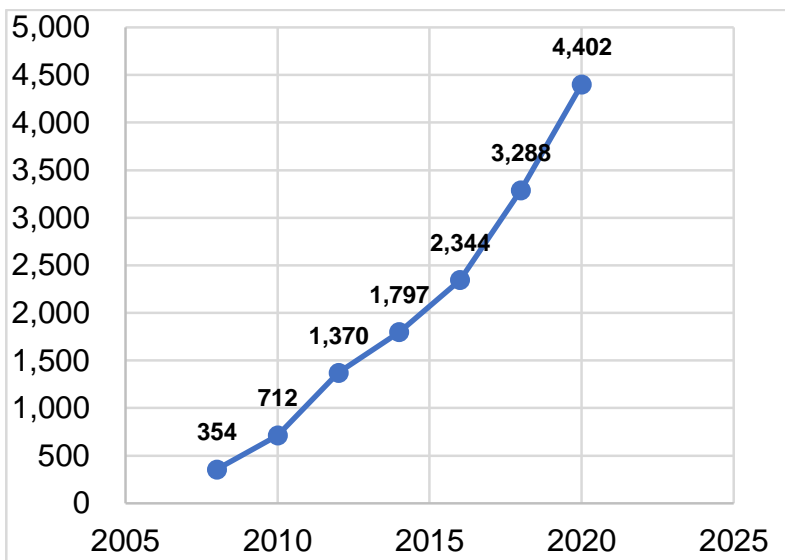

Figure 1 Net revenue of lululemon worldwide from 2008 to 2020 (in million U.S. dollars)

As figure 1 shown, the company's new revenue increased gradually between 2008 to 2020, which is collected from yahoo finance. In 2020, its revenue amounted to 4401.88 million dollars. However, in 2008, the net revenue was only353.59 million dollars. The firm developed quickly in the recent 12 years.

Table 1. Total number of lululemon athletica stores worldwide from 2019 to 2021, by country

\begin{tabular}{|c|c|c|c|}
\hline & 2019 & 2020 & 2021 \\
\hline United States & 285 & 305 & 315 \\
\hline Canada & 64 & 63 & 62 \\
\hline China & 22 & 38 & 55 \\
\hline Australia & 29 & 31 & 31 \\
\hline United Kingdom & 12 & 14 & 16 \\
\hline New Zealand & 7 & 7 & 7 \\
\hline Germany & 5 & 6 & 7 \\
\hline South Korea & 4 & 5 & 7 \\
\hline Japan & 5 & 7 & 6 \\
\hline Singapore & 3 & 4 & 4 \\
\hline France & 1 & 3 & 3 \\
\hline Sweden & 1 & 2 & 2 \\
\hline Malaysia & - & - & 2 \\
\hline Ireland & 1 & 1 & 1 \\
\hline Netherlands & - & - & 1 \\
\hline Norway & - & - & 1 \\
\hline Switzerland & 1 & 1 & 1 \\
\hline
\end{tabular}

Table 1 and figure 2 present the total number of lululemon athletica stores worldwide from 2019 to 2021 in a different country and comparable sales growth of lululemon worldwide from 2017 to 2020 in the quarter.
The detailed information would be found in these two graphs. We hold that the company's biggest market is in the US, and the second is China. The average trend is found from the quarterly data. 


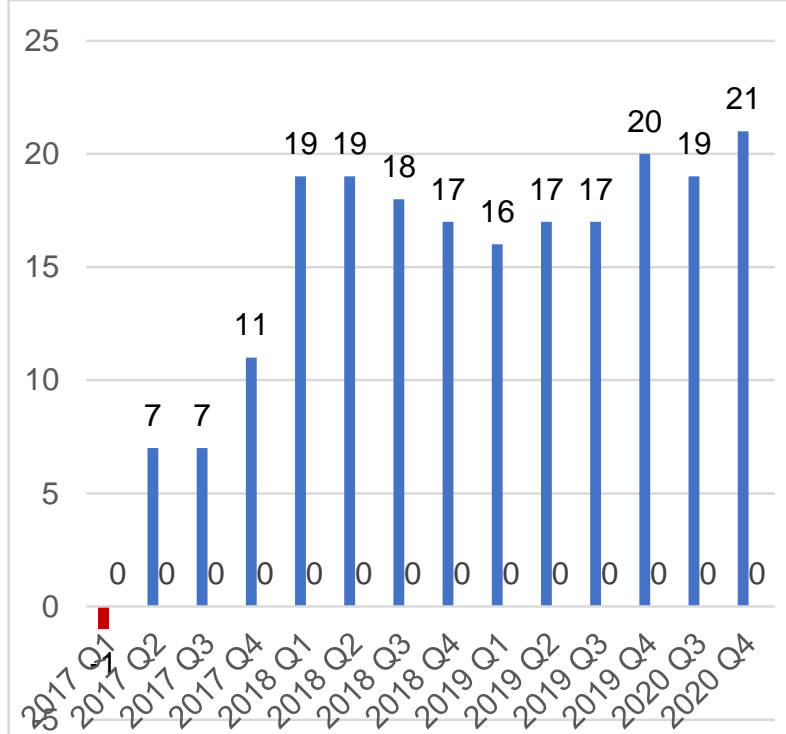

Figure 2 Comparable sales growth of lululemon worldwide from 2017 to 2020 , by quarter

\section{CONSUMER ANALYSIS}

When making decisions and making strategies, the brand should consider consumer characteristics and market segmentation. It identifies customer groups who share brand-related preferences [1]. Lululemon adopts a tailored segmentation method to attract specific market segments by responding to consumers' buying behaviour, customizing product lines, and marketing interactions.

When lululemon was founded in 1998, it was only a women's yoga apparel brand. It defines its user portrait like this: age between 24 to 36 years old, annual income of more than 80,000 US dollars, high education level, own house, spending one and a half hours to exercise every day, a super girl with a positive attitude towards life.

We can see that in this group, lululemon excludes girls in their early 20 s but favours women in the 24 to 36 years old age group. From the perspective of group characteristics, we can conclude that the former has youth capital, most of them are young and beautiful, have too many factors that may affect their shopping behaviours; in contrast, the latter not only has deeper pockets, but also more eager to change their life, but also want to keep figure. At the same time, they are perceived as successful people in the eyes of most.

The past success of Lululemon has left many consumers with the impression of a "female" brand. This impression will discourage many male consumers from it. So when it was determined to develop the male market, it began a reconstruction of the brand through weaken femininity and emphasize strength. At the same time, lululemon also considers avoiding female consumers feel abandoned. After all, the female market is still the main business.

There is no lack of technological breakthroughs in the sports and leisure field, but strong identity information is missing most of the time. Lululemon has just made up for this gap by selling a lifestyle represented by yoga.

\section{STRATEGY}

\subsection{Unique promotional strategy}

It is undeniable that the strategy of Nike and Adidas to harvest traffic and sales through the all-star lineup is very in line with the marketing trend. But how to distinguish from these brands and effectively compete with them is a topic worth thinking about. Lululemon provides us with a new idea through the strategy of building a brand-exclusive consumer community.

In terms of promotion, lululemon hardly advertises and does not sign traffic stars. Instead, it incorporates yoga coaches and even consumers into its marketing system. In other words, behind a pair of yoga pants, there are hundreds of KOLs in professional fields that allow you to try and interact with the brand in depth to the greatest extent, thereby creating stickiness. Specifically, lululemon will set up the position of "educator" at the beginning. Unlike ordinary salesmen, educators are well-versed in brand values and product features and the important task of finding store ambassadors. The store ambassador is usually the founder of a yoga studio or an athlete. Compared with Nike and Adi's tens of millions of brand endorsement fees, lululemon's return to store ambassadors is much stingier. In addition to new product fittings and gifts, professional photography benefits are also provided. However, the premise is that these photos have to be used as promotional materials for the brand for free. Lululemon will use these photos on store windows and social media such as ins, Twitter, WeChat, and Weibo to build its own brand community culture.

Although the cost is extremely low, lululemon has gained a very high market promotion effect.

On the one hand, this group of brand ambassadors are key opinion leaders within the community. Their consumption choices have a huge right to speak to potential customers in the region; On the other hand, compared to celebrities, this group of ordinary people around them is more influential. According to official data, lululemon has approximately 1,500 global store ambassadors; simultaneously, lululemon has signed 9 global yoga ambassadors among the top masters in the global yoga field, and then signed 35 elite ambassadors among international star athletes. Together they constitute the brand ambassador team of lululemon. 
Unlike other retailers who wait for customers to come to their door, lululemon's community sales strategy of "educator + brand ambassador + consumer" directly skips dealers, which not only establishes customer loyalty to the brand but also have more control over pricing, discounts, and marketing, and ultimately enjoy exclusive profits in the closed marketing loop is constructed.

\subsection{Brand community}

Lululemon did not spend too much energy to highlight the performance of its products but focus on telling you the lifestyle and culture. Many lululemon stores served both as yoga and fitness studios. The bottom of the hangers in the store is equipped with rollers. They can be pushed aside during non-business hours or when courses are held in store. The vacated area becomes a yoga practice place for customers. This approach has become one of the most critical business decisions in lululemon's history. It has become the core selling point of the brand and has continued to the present, and it has directly activated lululemon's sales. When old customers pass by themselves, they will habitually enter the store to take a look, and at the same time, they can take away a few items and bring likeminded friends to take a look. New customers will also be attracted by the novel way of operating the store + yoga studio.

Therefore, lululemon's store is not only a store but a community for yoga lovers. What's more interesting is that no matter whether people buy lululemon products or not, they can take part in various yoga classes conducted by store ambassadors. In fact, when people start the free yoga experience, they have also unlocked a series of hypotheses. As long as I wear lululemon, I can also have a good figure, and I can also live a fashionable and healthy life that makes people respect and yearn for. The in-depth interaction between consumers and potential consumers and the brand enables people to

better understand lululemon's brand culture, thereby establishing strong customer loyalty and generating purchase behaviour.

Lululemon also knows how to push his own experience to the extreme to stimulate fans' interest and network effects. The brand regularly sets up different themes every year. It launches large-scale brand events in different cities worldwide, such as the sweat festival in London, the marathon in Vancouver, and the beach party in Shenzhen Sweat life Festival, consolidating itself as a part of the city's culture. In addition, lululemon's social content also always revolves around lifestyle storytelling. In this way, a pair of yoga pants have been given more than wearing things-lululemon is not just a sports equipment shop but a synonym for sports and leisure activities in global metropolises and a global symbol of a fashionable and healthy lifestyle.

In addition to the exclusive brand sales community and lifestyle bundling, the high price is also the reason why lululemon stands out. A pair of yoga pants that cost thousands of dollars at every turn, although it is three times higher than most of its peers, has succeeded in keeping people other than lululemon's ideal users out of the price line.

\subsection{Target the male market}

Lululemon is a big success in the women's sports and leisure market by selling the lifestyle represented by yoga. There are many fans among the millennial generation, "Lulu pink" is spread worldwide. However, like other brands, such as Gap, Nike, and Under Armor, which have launched sports and leisure product lines at lower prices, Lululemon faces an extremely competitive market. It needs to develop new business. Lululemon's new strategic direction aims to the menswear market.

In terms of brand building, Lululemon mainly started from three aspects: first, nationwide advertising, emphasizing the technological attributes of the brand; second, opening a male-only retail store; third, adopting male image spokespersons. As a brand that started as a female yoga brand, Lululemon has played a technology card to persuade male consumers to abandon sportswear giants such as Nike and Under Armour, born with "male genes".

Lululemon's main product for men's clothing is ABC (Anti-Ball Crushing) pants. This $\$ 128$ trouser uses Lululemon's patented fabric Warpstreme corduroy. It has strong elasticity and is designed to solve the embarrassing problem of men's tight crotch. Lululemon quickly won positive feedback from the market by solving the male "crotch problem". This pair of trousers alone brought a $16 \%$ increase in same-store sales. Online reviews of this pair of trousers are also mostly positive. Many consumers have mentioned that it is suitable for many occasions. There are even consumers who have set up a website, LuluMen, specifically for it.

In terms of the overall menswear promotion strategy, although Lululemon has also opened several menswear stores, in general, it still sells menswear through existing stores. Lululemon's existing store traffic itself is very large and women are still the main shoppers, putting ABC pants next to women's jogging bras. When women are shopping for themselves, they may buy a pair of $\mathrm{ABC}$ pants.

In September 2020, Lululemon launched the first global campaign for the male market, changing the slogan to "This is Yoga". The promotion with the theme "Strength to Be" included 5 advertisements, reflecting 5 men showing their inner strength and self-awareness. 
This strategy worked quickly. The financial report for the second quarter ended July 30 showed that Lululemon achieved a comparable sales growth of $7 \%$, exceeding Consensus Metrix's comprehensive forecast of $4 \%$, and reversing the $1 \%$ short-term decline in the first quarter, earning its place in the North American leisure sports market.

\section{FIVE FORCES ANALYSIS}

The framework provides a qualitative and comprehensive strategic analysis. Porter's five forces model will help lululemon establish a strategic position and create a competitive advantage.

\subsection{Threats of new entrants}

Lululemon is a pioneer in sports and leisure brands, and the company has a long history of creating innovative products. It operates an innovation center called Whitespace in Vancouver and New York to create new value propositions for customers. It is joining up with fashion designers to produce new clothing styles and widen its product lines to develop effective barriers to protect its competitive advantage.

\subsection{Bargaining power of suppliers}

Since Lululemon does not operate any production facilities, the suppliers have high bargaining power. Lululemon's raw materials come from 65 suppliers, of which $30 \%$ of Lululemon products are made from a registered trademark supplier called Luon.

\subsection{Bargaining power of buyers}

Due to the high price of Lululemon, buyers have very low bargaining power. Lululemon's strategy for the high-end market has proven to be successful. It has maintained a competitive advantage.

A strong brand association with the luxury sports and leisure market creates a sustainable competitive advantage. It continues to attract new buyers because consumers want to buy lululemon products to show their identity.

\subsection{Threat of substitutes}

Lululemon has a solid and loyal customer base. The company has a large following and has created a unique community for the health and fitness market. Lululemon turned the store into a yoga studio to maintain a stable community and provide services other than clothing products.

\subsection{Rivalry among competitors}

The competition among existing players is fierce. The sports clothing industry is highly fragmented. Competitors use pricing strategies to drive down prices, increase market share, and reduce overall profitability. The highly competitive sports and leisure market has become a real threat to Lululemon in the high-end market. The economic downturn will cause consumers to switch to more affordable brands.

\section{SWOT ANALYSIS}

SWOT analysis is a technique developed at Stanford in the 1970s, frequently used in strategic planning [9]. SWOT is an acronym for Strengths, Weaknesses, Opportunities, and Threats and is a structured planning method that evaluates those four elements of an organization, project, or business venture. A SWOT analysis is a simple but powerful framework for leveraging the organization's strengths, improving weaknesses, minimizing threats, and taking the greatest possible advantage of opportunities [10]. We utilized SWOT analysis to analyze the lululemon.

\subsection{Strength}

Unlike competitors such as Nike or Adidas, which spend millions of dollars on advertising, Lululemon Athletica chooses to target influential people such as fitness coaches or yoga masters, give them gifts, and then use them to influence target groups and buy their clothing. Targeting the influencer is playing a more significant role than traditional advertising. It is effective because influencers can interact with consumers on a personal level. Lululemon Athletica is a brand with a high level of customer engagement.

\subsection{Weakness}

Compared with its competitors, Lululemon has been cautiously expanding and has not been too aggressive, which may affect its long-term growth prospects. Its inability to penetrate successfully in foreign markets may hinder the development.

Although lululemon athletica has a solid customer base, their products cater to the high-end market, so the brand must rely on value rather than sales. As a result, the profit margins of all the company's products are low.

\subsection{Opportunity}

The world sports apparel industry is expected to increase manifold. And the market is driven by a trend toward healthier, more active lifestyles, with older demographics and women are playing a more active part within it. Lululemon is expected to have better reach and penetration into emerging economies. 


\subsection{Threat}

The sportswear industry is highly fragmented, with many brands competing, from basic discount brands to high-end fashion brands. Challenges facing sportswear companies include changing fashion trends, fierce competition, and consumers becoming more pricesensitive.

\section{CONCLUSION}

The case of lululemon embodies a new brand strategy: establishing a unique brand positioning, using various effective channels of emotional marketing to enable consumers to have a sense of identity and belonging to the brand, thereby forming a good cultural atmosphere, using culture to gather consumers and form brand online and offline consumer communities. This strategy effectively distinguishes itself from the strong brands in the field. Lululemon not only represents yoga clothing. It is also synonymous with fashion and social tools but also means a high-quality lifestyle. We also analyze the Strength, Weaknesses, Opportunities, and Threats to this company. A series of recommendations would be proposed.

This article also exists the limitation. In this article, we collected little data on the market condition. In the future, we would investigate the market in detail and present some quantity models on the research.

\section{REFERENCES}

[1]. Lavrence, C., \& Lozanski, K. (2014). "This Is Not Your Practice Life": lululemon and the Neoliberal Governance of Self. Canadian Review of Sociology/Revue canadienne de sociologie, 51(1), 76-94.

[2]. Tybout, A. M. (2017). Lululemon Athletica. Kellogg School of Management Cases.

[3]. Ganin, C. (2014). American Apparel, Crumbs Cupcakes, and Lululemon, Oh My-Examples of Why Increased Shareholder Invovlement Will Not Fix Corporate America. Ariz. L. Rev., 56, 937.

[4]. Baalbaki, S., Gilliard, D. J., \& Hoffman, D. L. (2019). Is Lululemon Athletica's Turnabournd Sustainable?. American Journal of Management, 19(2), 26-39.

[5]. Sanford, B. (2021). Marketing Lululemon in Nigeria.

[6]. Smith, S., Ownby, M., \& Kim, Y. K. (2018, January). The Rise of Athleisure and Its Impact on lululemon. In International Textile and Apparel Association Annual Conference Proceedings (Vol. 75, No. 1). Iowa State University Digital Press.
[7]. Leigh, D. (2009). SWOT analysis. Handbook of Improving Performance in the Workplace: Volumes 1 - 3, 115-140.

[8]. Sousa, S. (2016). Lust for Lulu: An Examination of Lululemon Athletica's Marketing Authenticity and Branding.

[9]. Elavarasan, R. M., Afridhis, S., Vijayaraghavan, R. R., Subramaniam, U., \& Nurunnabi, M. (2020). SWOT analysis: A framework for comprehensive evaluation of drivers and barriers for renewable energy development in significant countries. Energy Reports, 6, 1838-1864.

[10].Abdel-Basset, M., Mohamed, M., \& Smarandache, F. (2018). An extension of neutrosophic AHPSWOT analysis for strategic planning and decision-making. Symmetry, 10(4), 116. 